\title{
НОВОЕ ОБЪЯСНЕНИЕ ХОДА ВСЕМИРНОЙ ИСТОРИИ *
}

\section{ПАВЕЛ МИЛЮКОВ}

\begin{abstract}
Публикуется развернутая рецензия Павла Милюкова на классическую книгу Александра и Евгения Кулитеров «Войны и миграции. Всемирная история как движение народов» (1932). Милюков, известный русский историк и политик, напечатал этот отзыв в эмигрантской газете «Последние новости», издававшейся им в Париже между двумя мировыми войнами. Рецензия сопровождается предисловием и комментариями к тексту. В предисловии представлена история создания книги братьев Кулишеров. В нем, в частности, подчеркивается решаюшая роль известного русского историка и социолога Михаила Кулишера, отцฺа авторов, в разработке оригинальной теории миграции, на которой основана эта книга. Отмечаются его более чем сорокалетние усилия по сбору материалов о мировой миграции, которые были использованы в книге сыновей.
\end{abstract}

Ключевые слова: теория миграции, войны и миграции, Александр Михайлович Кулишер (1890-1942), Евгений Михайлович Кулишер (1881-1956), Михаил Игнатьевич Кулишер (1847-1919).

В 1932 г. была опубликована книга Александра и Евгения Кулишеров «Войны и миграции. Всемирная история как движение народов» [Kulischer, Kulischer 1932], которая стала важной вехой в развитии мировой миграциологии. Эта книга, хотя и появилась на немецком языке, несомненно, является продуктом русской школы социальной мысли. Братья Кулишеры, которые были членами конституционно-демократической партии, вынужденно покинули большевистскую Россию в 1920 г. и работали над своей книгой уже в условиях эмиграции.

Книги имеют свою историю, которая иногда может быть долгой и необычной. В книге братьев впервые полностью представлена теория миграции, начало которой задолго до того положил их отец Михаил Кулишер (1847-1919). Как удалось установить, исследование миграции было главным делом жизни этого известного историка и социолога, который посвятил изучению данной тематики более сорока лет [Тольц 2004b]. Впрочем, Михаил Кулишер успел опубликовать только одну статью, где лишь наметил основные черты своей оригинальной теории миграции и применил ее к некоторым миграционным движениям [Кулишер 1887]. Но после его смерти остались обширные материалы, собранные им за долгие годы исследований. Именно теория отца и накопленные им материалы легли в основу книги братьев Кулишеров, которые при ее написании обогатили семейное исследование использованием многочисленных источников, появившихся после кончины их отца.

\footnotetext{
ПАВЕЛ МИЛюКов. (1859-1943)

* ПРЕДИСЛОВИЕ, ПОДГОТОВКА ТЕКСТА И КОММЕНТАРИИ МАРКА ТОЛЬЦА.
}

МАРК ТОЛЬЦ. ИЕРУСАЛИМСКИЙ УНИВЕРСИТЕТ. ИЗРАИЛЬ. Е-MAIL: mark.tolts@mail.huji.ac.il.

СТАТЬЯ ПОСТУПИЛА В РЕДАКЦИЮ В МАЕ 2015 Г. 
В дальнейшем братья продолжили свои исследования на материалах первой половины XX века [Тольц 2004а]. Но теоретическая основа их исследований осталась прежней. Она унаследована от отца. Стоит отметить, что даже в последней книге Евгения Кулишера «Европа в движении: война и изменения населения, 1917-1947» [Kulischer 1948] теория миграций, как она представлена в ней в специальном разделе, является в основном кратким изложением того, что уже было опубликовано в книге братьев [Kulischer, Kulischer 1932].

Несмотря на то, что эта книга братьев Кулишеров до сих пор не переведена с немецкого на другие языки, она, несомненно, вошла в число классических исследований и часто цитируется в работах, посвященных всемирной истории населения. Фрэнк Лоример включил ее в перечень главных публикаций при написании им авторитетного очерка истории мировой демографии [Lorimer 1959]. При этом он отметил, что передвижения населения всегда были объектом, который стоял в центре внимания русских историков. В свою очередь Николай Тимашев привел эту книгу в своем списке наиболее важных работ в истории мировой социологии [Timasheff 1955: 313]. Отметим также, что ее материалы широко использованы Фернаном Броделем в его классическом труде «Материальная цивилизация, экономика и капитализм», где они служат основой для описания миграций в Евразии в XIV-XVIII веках. По ним Бродель подготовил две карты для своей фундаментальной работы, которые мы воспроизводим (см. рисунок). Братьев же он представил читателю следующим образом: «Два великолепных историка» [Бродель 2006: 65]. Упоминал Бродель их в ряду выдающихся историков населения и в другой своей работе [Braudel 1960].

Впрочем, Евгений Кулишер, который надолго пережил погибшего в годы Второй мировой войны брата, считал, что не все было замечено современниками в их книге. Так, в одной из своих рецензий он обращает внимание на страницы 139-140 этой книги, где, по его мнению, еще до Фрэнка Ноутстайна (Адольфа Ландри он не упоминает) уже была сформулирована теория демографического перехода [Kulischer 1954]. Возможно, отмеченное станет поводом для специалистов в области демографической революции вновь обратиться к истории этой концепции.

Появление книги братьев вызвало многочисленные отклики современников. Среди тех, кто написал о ней, был Павел Милюков, известный русский историк и политический деятель, который в своих исследованиях уделял большое внимание проблемам динамики населения. Поэтому неслучайно, что в издававшейся им в Париже газете «Последние новости» он поместил развернутую рецензию на эту книгу [Милюков 1932]. Несколько позднее был опубликован также ее вариант на французском языке [Miljukov 1933]. В своей рецензии Милюков подробно остановился на содержании книги братьев и поднятых в ней проблемах. Он отметил ее несомненные достоинства, но при этом не обошел молчанием и проблемные моменты работы. Милюков был не только известным историком, но и прирожденным политиком. Он обращает особое внимание на нерешенные тогда - да и сейчас! - вопросы политики в области регулирования миграций. 


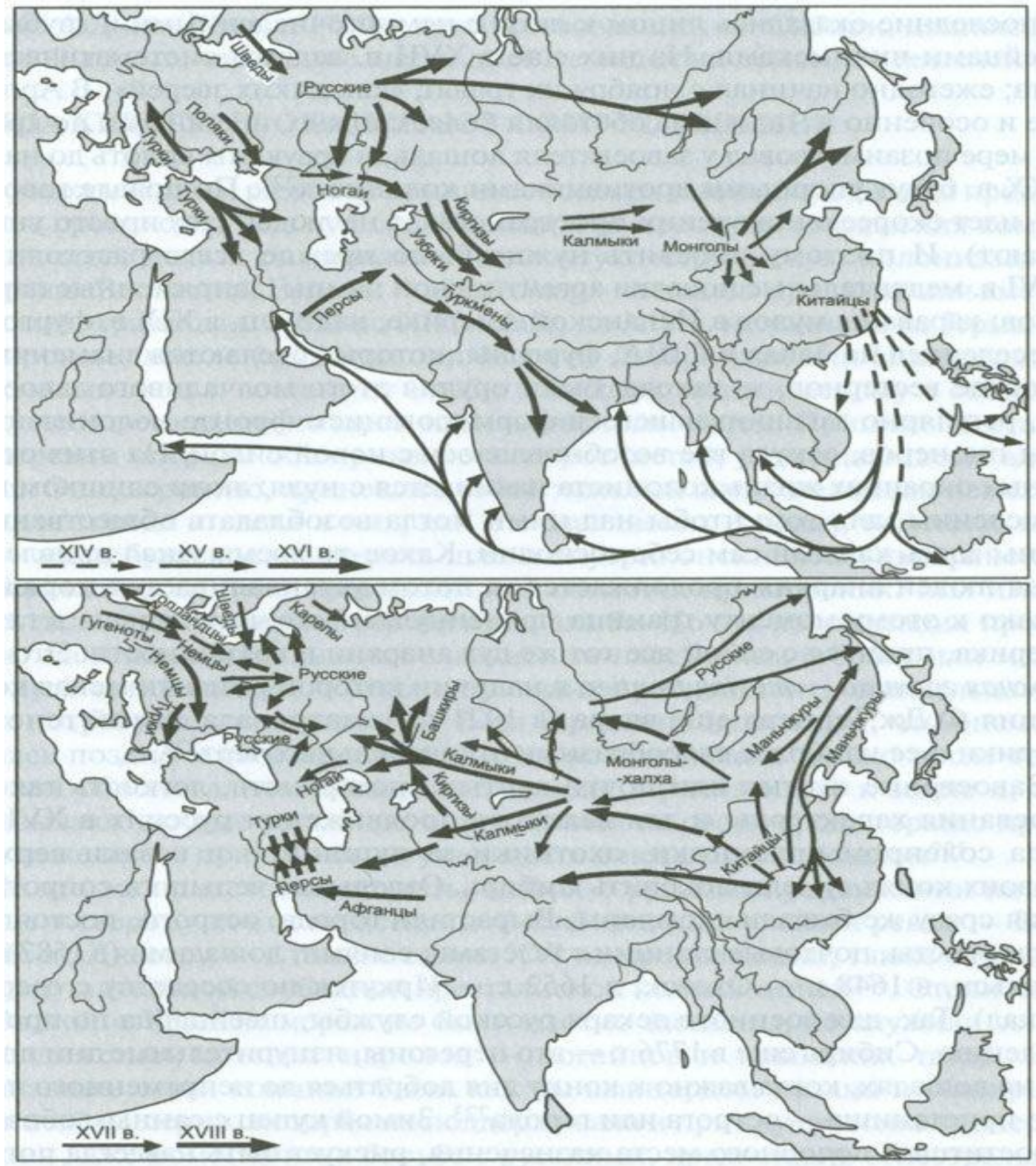

Рисунок. Миграции в Евразии, XIV-XVIII вв.

Источник: По данным А. и Е. Кулишеров [Бродель 2006: 67].

Книга братьев Кулишеров [Kulischer, Kulischer 1932], к сожалению, остается до настоящего времени практически недоступной российскому читателю. Она отсутствует даже в собраниях крупнейших библиотек Москвы и Петербурга (на этот факт указал М.Б. Денисенко при обсуждении с автором данного предисловия судьбы научного наследия Кулишеров). Потому публикация обстоятельной рецензии Милюкова может, наконец, послужить началу знакомства - пусть и очень запоздавшего - российских исследователей с этой замечательной работой. Публикуемый текст рецензии Милюкова, появившейся в его газете, приводится в соответствии с правилами современной орфографии при сохранении особенностей пунктуации автора. 


\section{ПАВЕЛ МИЛЮКОВ}

\section{НОВОЕ ОБЪЯСНЕНИЕ ХОДА ВСЕМИРНОЙ ИСТОРИИ}

Значение книги, составленной братьями А. и Е. Кулишерами, явствует из самого заглавия $\mathrm{ee}^{1}$. Это - попытка объяснить ход всемирной истории передвижениями народов. «Великие движения народов, давящих друг на друга и толкающих вперед, являются истинными руководящими линиями мировой истории. Они проявляются в форме длинных цепей переселений, в разбойничьих и военных походах и завоеваниях. Глубоко под цветистой оболочкой исторических событий действуют эти простые, механические элементарные силы; в сущности, именно они отделяют друг от друга различные эпохи истории». История представляется с этой точки зрения слепым стихийным процессом. И хотя авторы признают, что по мере приближения от древности к нашему времени формы и пути, в каких и какими проявляет себя стихия, значительно изменяются, - тем не менее, они заканчивают книгу мрачным аккордом: человечество еще не дошло, — и было бы утопией надеяться, что оно скоро дойдет, - до рационального способа предупреждать и направлять к благу царящие в мире стихийные силы.

Как видим, задача, поставленная авторами, грандиозна. Но нельзя сказать, чтобы они предприняли ее осуществление с недостаточными силами. Внести в наше время в науку новое толкование хода истории, конечно, было бы непосильно для всякого. Но авторы имеют предшественников. Следя за их ссылками на литературу в обширных примечаниях, нельзя не поддаться впечатлению громадности выдвинутой ими тяжелой артиллерии строго научных исследований. Их синтез, как оказывается, сложился из мозаики многочисленных отдельных достижений ученых, принадлежащих разным странам и национальностям. Едва ли все эти исследователи имели в виду общий характер постройки, когда обтесывали для нее отдельные куски. Но тем значительнее заслуга строителей, сумевших собрать по мелочам все эти материалы и вывести из них свое стройное здание. Оригинальность А. и Е. Кулишеров, конечно, не в самостоятельном изучении всех использованных ими подробностей, - это было бы недоступно современному ученому, - а именно в их сопоставлении, в умении найти в каком-нибудь завалящем уголке специальной статьи или тяжеловесного ученого исследования как раз ту бьющую в точку цитату, которая нужна и убедительна для каждого положения их сводной работы. Обращу внимание также на то, что большая часть ссылок сделана на работы последнего пятнадцатилетия. Это само по себе показывает, что начатый полвека назад отцом авторов, М. Кулишером (сконч. в 1919 г.), научный труд совершенно обновлен его сыновьями. Отдавая должное сыновнему пиетету, мы должны отметить и эту долю их личной заслуги.

При огромности поставленной задачи, нельзя пенять на авторов, что они ограничили ее выбором из всей истории только трех показательных периодов, составивших содержание трех глав книги: 1) «военные походы н переселения варварских народов; колесо мировой истории VII - X столетий»; 2) «течения передвижений в век абсолютизма; отлив и прилив между Востоком и Западом в XVI - XVIII столетиях», и 3) «движение кругом света и мировая катастрофа» (XIX и XX столетия). Выпали, таким образом, доисторические

\footnotetext{
${ }^{1}$ Kriegs- und Wanderzüge. Weltgeschichte als Völkerbewegung, von Alexander und Eugen Kulischer. Mit 3 Karten. 1932. Walter de Gruyter und Co., Berlin und Leipzig.
} 
миграции и эпоха переселения народов. Очевидно, авторы руководились при этом большей изученностью избранных ими периодов и возможностью доказать на более бесспорных данных утверждаемые ими тезисы.

Теоретической установке этих тезисов посвящена вступительная глава. Здесь, прежде всего, необходимость переселений доказывается потребностью человеческих обществ, при размножении населения или при истощении питательных ресурсов, искать новых или увеличенных средств существования. Впрочем, в этой формулировке понятия «размножения» населения и «увеличения» средств питания (на том же месте жительства) отодвигаются авторами на второй план, сравнительно с понятиями «истощения ресурсов» и поисков «новых средств». Размножение населения (в периоды мира) они объясняют, где только можно, не увеличением количества рождений (фактор, который не действует сразу), a уменьшением смертности. Что касается увеличения средств пропитания путем интенсификации труда (т.е. внутренним процессом), [то] они совсем его отстраняют, ибо такая интенсификация «предполагает переворот всей хозяйственно-социальной организации». Таким образом, перемены в размерах питательных средств мотивируются, главным образом, появлением новых пришельцев или запустением после войны, эпидемий, ухода населения - и совершаются «катастрофически». Основная причина передвижений сводится при этом к стихийной потребности «выравнивания» между территориями большей и меньшей («относительной») насыщенности питательными средствами.

При таком упрощении подлежащих изучению явлений, бросается в глаза одно: игнорирование (или намеренное устранение?) природных различий климата, почвы, растительности между территориями, между которыми «равновесие» нарушено, - т.е. устранение из исследования элемента антропогеографического. Авторы хорошо знают Ратцеля ${ }^{2}$, как «основателя антропогеографии», и часто цитируют его «Политическую географию». Но они совершенно не обнаруживают знакомства с его основным и лучшим трудом «Антропогеографией». Конечно, они вспоминают как об элементах, нарушающих прямую линию переселений, о препятствиях, полагаемых переселению горами, морем, даже «густым лесом». Но они считают такие «естественные свойства стран» препятствиями второстепенными и останавливаются лишь на отрицательной стороне их влияния. Оттого у них территории выселения и вселения как-то обезличиваются, и основной принцип их теории - нарушение равновесия плотности населения ${ }^{3}$ - получает несколько абстрактный характер. Это отражается, например, в частном случае борьбы «пустыни и культурной территории», полным исключением наиболее частого реального исхода такой борьбы [-] симбиоза кочевника и земледельца на основе - не разрушения культуры, а сожительства, основанного на подчинении. Элиминируя, по возможности, такие способы сравнительно мирного разрешения нарушенных равновесий, авторы, естественно, выдвигают на первый план как наиболее частые и, в известном смысле, нормальные случаи - случаи вооруженного нападения, сопровождаемого вытеснением пришельцами туземцев. На этом основывается и их классификация трех основных форм

\footnotetext{
2 Ратцель, Фридрих (Friedrich Ratzel, 1844-1904) - немецкий географ и этнограф. Упом. далее книги: [Ratzel 1882-1891; Ratzel 1897].

${ }^{3}$ Точнее, сравнительной («хозяйственной») густоты населения, по словам самого автора рецензии (см. ниже).
} 
народных передвижений: передвижения, толкающего дальше, вперед население, вытесняемое новыми пришельцами; передвижения, наоборот, притягивающего население с тыла на покинутые переселенцами места, и, наконец, непрямого развития движения, если дорога по прямой линии закрыта другим «самостоятельным переселением». «Само собой разумеется, - оговариваются они, - что это - только схематическая классификация, вовсе не претендующая исчерпать богатое разнообразие исторических событий». И надо отдать им справедливость: во всех отклоняющихся от схемы случаях они добросовестно указывают причины отклонений и осложнений. Но это не мешает им идти в своей работе по намеченным руководящим линиям, осуждая тем некоторые их выводы на абстрактность и преувеличение. Необходимо, впрочем, сразу же признать, что даже и выводы, кажущиеся читателю слишком смелыми в своей односторонности, все же будят исследовательскую мысль и делают их исследование, как выражаются немцы, anregend ${ }^{4}$.

Для более широкого круга читателей наибольший интерес представляет, конечно, последняя глава, трактующая о трагической конъюнктуре современности. Но специалисты заинтересуются и двумя предыдущими главами, на которых мы остановимся в общих чертах. «Колесо всемирной истории VII - X столетий» составляется авторами из многочисленных кусков, которые мы не привыкли связывать вместе. Основной толчок движению «колеса» дают арабы. Но не Ислам приводит арабов в движение, а предшествующее проповеди Ислама запустение Аравии. Первый полный оборот колеса совершается в VII - VIII столетиях кругом Черного моря. Арабы бросаются на Сирию и Месопотамию, встречают сопротивление в Малой Азии и в Армении, но пробираются на Кавказ, отрезают там путь на юг хазарских набегов и заставляют хазар передвинуться на Днепр; оттуда хазары выгоняют болгар 5 за Дунай, в пределы византийской империи; болгары толкают славянских беглецов к Константинополю - навстречу беглецам из Малой Азии, спасающимся от арабов. Так замыкается первый круг. Второй, более широкий оборот колеса происходит кругом Средиземного моря. Сперва арабы движутся по северному берегу Африки в Испанию, куда они увлекают с собой берберов; потом берберы выгоняют испанское население на север в горы и в южную Францию, за Пиренеи. Франки, в свою очередь, совершают набеги на северную Италию, за Рейн, на саксов. Саксы, передвигаясь от них на север, закрывают дорогу скандинавской экспансии с севера и вызывают ее отклонение к юго-западу: морские набеги норманнов. Следующее звено: германцы двигаются на восток и разрушают аварское царство, освобождая Паннонию ${ }^{6}$ для славян; в то же время потесненные на Висле славяне двигаются еще дальше на восток и расселяются по Днепру. Авторы находят подкрепление для каждого из перечисленных звеньев в сравнительном запустении областей, в которые совершается вселение. Должен только прибавить, что поддержка, найденная для изображения движения славян на восток у Шахматова ${ }^{7}$, недостаточно тверда, ибо Шахматов относит это движение к слишком позднему времени:

\footnotetext{
${ }^{4}$ Стимулирующим.

5 Здесь речь идет о тюркских племенах протоболгар, принявших участие в этногенезе современных болгар, государству которых они передали свое имя.

6 Регион в центральной Европе, бывшая римская провинция, территория которого включает современную Венгрию, восток Австрии, юго-запад Словакии, север Словении и Хорватии, северо-восток Сербии, север Боснии и Герцеговины.

${ }^{7}$ Шахматов, Алексей Александрович (1864-1920) - русский филолог и историк. 
теория Шахматова не может считаться признанной в науке ${ }^{8}$. Изображается, далее, и третий оборот колеса, захватывающий Переднюю Азию. Сперва сюда проникают те же арабы, доходящие до Туркестана; потом, под влиянием переменного счастья Китая и усиливающихся набегов тюрков, движение поворачивается на запад, в русские степи, выгоняет славян на север и на запад (снова, - это самое сомнительное из звеньев), и сопровождается победами венгров в бассейне Дуная. Французы отбрасываются к Пиренеям и переходят их; начинается движение испанцев к югу; берберы вытесняются в Африку и проходят, в обратном порядке, до Египта и за Суэцкий перешеек; а разбитые тюрками арабы возвращаются к себе в Аравию, замыкая круг колеса.

Я не могу судить, насколько прочно связаны все звенья этой грандиозной цепи передвижений. Но большая часть их представляется мне достаточно обоснованной. Настолько позволяют источники, и приведение этих движений в связь с колебаниями сравнительной («хозяйственной») густоты населения в отдельных странах кажется весьма вероятным. Во всяком случае, сколько мне известно, такая широкая картина передвижений данной эпохи набрасывается впервые.

Предмет второй главы - переселения в век абсолютизма (XVI - XVIII в.), представляют для авторов то удобство, что лучше освещены источниками и исследованиями. Но тут является и то неудобство, что переселения представляют здесь иной характер и проявляются в иных формах, чем в век «варварства». «Война и переселение здесь уже не тождественны; но они, по-прежнему, тесно связаны друг с другом. А именно, избыток населения утилизируется для войска; армия становится «учреждением призрения для безработных». Но такую, более многочисленную армию надо содержать; тягота налогов не только достигает предела, выносимого для населения, но и переходит зачастую этот предел, вызывая этим «обратный мальтузианский процесс» уменьшения питательных ресурсов, бегство населения и запустения страны, - если только невозможно переложить издержки милитаризма на соседние страны, т.е. разорить и разграбить их военным нашествием. Иногда оказывается возможным в этих «военных странствиях» нагнать своих беглецов и обратить их тоже в солдат и обложить налогами: это случай русской колонизации юга.

Что касается установки целой «цепи» переселений, здесь, по конструкции авторов, она принимает сперва характер «притягивающий». «Притягивает» переселенцев на восток именно китайское движение к юго-востоку. Оно вызывает движение монгольских кочевников на Китай; а на оставленные монголами места продвигаются «татарские» кочевники, ногайцы, узбеки, киргиз-казаки ${ }^{9}$, переходя с Волги на Урал, с Урала в теперешний Казахстан, оттуда в Туркестан, из Туркестана, - Бабер ${ }^{10}$, — в Афганистан, пока, наконец, тот же Бабер не основывает царство «Великого Могола» в Индии (1525 1605). Именно благодаря этому передвижению на Восток, рождается Золотая Орда, Россия освобождается от татарского ига, и начинается ее продвижение на оставленные населением места, - за Волгу, в Сибирь и в южные степи. Однако, это движение русских переселенцев

\footnotetext{
${ }^{8}$ Подробно позиция автора рецензии по данному вопросу изложена в: [Милюков 1993: 380-468].

${ }_{9}^{9}$ Устаревшее название казахов.

${ }^{10}$ Правнук Тамерлана, основатель империи Великих Моголов в Индии; в современном написании - Бабур.
} 
на восток повело, в связи с увеличением налоговой тягости, к запустению центра и к ослаблению власти на западной границе. Этим авторы объясняют неудачи ливонских походов Ивана Грозного и - подготовку смуты. Слишком смелым кажется после этой правдоподобной картины объяснять теми же демографическими причинами и движение шведов к Новгороду и поляков к Москве. Здесь - предел, за которым чисто стихийные процессы, наблюдаемые авторами, осложняются политическими, более или менее целесообразными, которые, однако же, авторы стараются также представить, как видоизменение тех же стихийных.

Следуя своей идее «притягивающей» к востоку цепи переселений с запада, авторы устанавливают и факты передвижений из Польши в Заднепровье, из германских земель в Польшу, из Нидерландов в Германию, и, наконец, из Франции на Рейн. Тридцатилетняя война и неудачи последних походов Людовика XIV — крупнейшие исторические события XVII в. и начала XVIII в., сопровождаемые запустением Германии и Франции (сюда присоединяется и Испания), находят себе объяснение в тех же, вышеуказанных, демографических явлениях. Тем же самым объясняются и промышленные успехи Голландии и Англии, принявших к себе «истинное народное переселение» изгнанных из Франции гугенотов ${ }^{11}$ (подобное же явление - изгнание морисков ${ }^{12}$ из Испании). У читателя является, естественно, такое же сомнение в полноте и достаточности такого объяснения, какое являлось раньше, - при объяснении одной демографией завоевательных походов Ислама, создания империи Карла Великого, итальянских походов Оттонов саксонских ${ }^{13}$ и образования государств норманнами. Но часть этих сомнений придется, вероятно, отнести на долю неподготовленности читателя к чисто стихийным объяснениям всех этих процессов, т. е., в сущности, на долю новизны защищаемой авторами теории.

K концу XVII в. и к началу XVIII-го направление общей «цепи» движений — с запада на восток - радикально и резко меняется, заменяясь движением прямо противоположным - с востока на запад. Основною причину этой перемены авторы опять находят в событиях [в] Восточной Азии. Там маньчжурская династия Китая (с 1644 г.) покорила восточные племена монголов, которые, в свою очередь, бросились на татар Халхи ${ }^{14}$, а последние стали грозить Красноярску, Кузнецку и Томску, полагая этим предел русской колонизации Сибири. «Новое монгольское нашествие» стало грозить и России со стороны скотоводов Приуралья. Ногайцы, башкиры, калмыки, киргиз-казаки грабили русский юго-восток, где русская колонизация не успела закрепиться. Авторы отмечают участие этих племен в войсках Разина. Но и самый поворот Петра Великого с востока к западу становится одним из звеньев той же «обратной» цепи. Собирая армии из «безработных», облагая население трудовой повинностью и налогами, расквартировывая полки по губерниям, опустошая Россию, Петр подчинялся такой же необходимости, которая привела в подобное же состояние запустения современную ему Швецию, естественно потерявшую свои заморские владения, включая и опустевший Прибалтийский край. Однако, авторы признают, что

\footnotetext{
11 Протестантов.

12 Мусульман.

${ }^{13}$ Германские короли, обладатели императорского титула Священной Римской империи.

${ }^{14}$ Историческая область Монголии, расположенная к северу от пустыни Гоби. 
достигнутая на западе «высшая культура», - включая и Россию, - на этот раз заперла кочевникам «двери из Азии в Европу». И «обратное движение» на запад остановилось, поставив лишь предел движению России на Дальний Восток, в приморскую область.

Наибольший интерес для читателя представляет, как сказано, последняя глава книги, посвященная «кругосветному движению» народов и современной «мировой катастрофе». Источники здесь изобилуют, включая и скудную до сих пор статистику. Но снова увеличиваются и трудности для теории авторов, отмеченные уже по поводу предыдущей главы: трудности одностороннего объяснения событий - стихией. Одерживают ли авторы победу и над этими трудностями?

Переселения не прекращаются и в XIX в., - отвечают они. И причины их те же, что прежде. Но коренная разница - в том, что вместо поступления в войска и нападения на соседей, «безработные» или «лишние» люди переправляются за океан в ненаселенные, свободные для колонизации страны. Девственный простор этих стран кажется беспредельным; не знает пределов также и работающая на вновь открывшиеся рынки промышленность. Население, которое не едет в Америку, приливает в города. И начинается изумительная эпоха непрерывного роста человечества. «В 1800 г. насчитывалось в мире 850 миллионов людей; в 1900 г. это число удвоилось ${ }^{15}$. В одно столетие, таким образом, удвоилось то число, до которого дошло человечество в предыдущие 500.000 лет. В течение 800 лет — от 1000 до 1800 года — белая раса разрослась с 30 до 210 миллионов. А в следующие 115 лет эта цифра поднялась до 645 миллионов». С этой цитаты начинается последняя глава. Если такой рост не вызвал немедленно ужасов, сопровождающих перенаселение, то это, как указывают авторы, произошло по двум причинам. Первая - уже указанное переселение излишка в заокеанские страны. Вторая, - на ней особенно настаивают авторы, - та, что рост населения вызывался не столько увеличением рождаемости, которая, напротив, непрерывно падала с середины XIX столетия, - сколько уменьшением смертности - плод успехов гигиены и санитарии в народных массах. C течением времени первая цифра - уменьшение рождений - догоняет вторую уменьшение смертности, т.е. уменьшение смертности с излишком покрывается уменьшением рождений, и население становится стационарным или даже начинает убывать. Но, с другой стороны, к концу эпохи, т.е. к нашему времени, заполнялся и резервуар свободных земель, сокращалась емкость рынков сбыта для беспредельно выраставшей индустрии, борьба за оставшиеся свободными земли и рынки, сменяла прежнюю свободу переселений и фритредерство ${ }^{16}$; переселение принимало былые формы элементарной национальной борьбы. Последняя мировая война явилась исходом из сложившегося напряжения, вылившегося, таким образом, в мировую катастрофу ${ }^{17}$.

Эта общая картина расчленяется авторами на группы отдельных явлений, принимающих связный вид двух гигантских «цепей». Симметрия здесь получается, в руках

\footnotetext{
${ }^{15}$ Впоследствии динамика численности населения Земли была уточнена: 968 млн в 1800 г. и 1.613 млн в 1900 г. [Biraben 2006: 13].

${ }^{16}$ Свобода торговли.

17 Применительно к России об этом еще в 1924 г. было подробно написано в статье одного из соавторов рецензируемой книги: [Кулишер 2014].
} 
авторов, еще более изумительная, чем в двух предыдущих периодах. Два могучих людских потока $^{18}$ : один на запад, другой на восток от центральной линии водораздела, - почти совершенно совпадающей с послевоенной границей России, - таковы общие штрихи этой картины. На запад от теперешней русской границы с лимитрофами ${ }^{19}$, движение направляется за океан. На востоке от этой границы идет заселение Азии. Симметрия выдерживается и в дальнейших деталях. Один за другим, в последовательном порядке близости к океану, движутся в Америку три волны переселенцев: первая из Ирландии, Англии и германских земель до Эльбы; вторая - из заэльбской Германии, верхнего Дуная и Швейцарии; третья и последняя - из области русских лимитрофов, Польши, Румынии, Венгрии, Балканского полуострова и Италии. Хронологические границы этих трех эмиграций авторы определяют 1850-м и 1880-м годом. В таком же порядке трех последовательных волн движется и переселение на восток, в азиатские земли - тоже по степени близости или, отдаленности от Урала. Хронологические границы этих трех эмиграций в Сибирь определяются 1880 и 1890 годами. Первыми идут на восток обитатели Оки и Поволжья. Вторым поднимается русское население, живущее на восток от Днепра. Наконец, с 1900 года приходят в движение и догоняют предыдущие волны белорусы и украинцы.

Из всей этой картины составляют исключение лишь Испания и Франция. Последняя, со своим стационарным населением, является даже страной не выселения, а вселения испанцев, итальянцев, немцев, поляков. Судьбу трех эмиграций за океан авторы прослеживают и в Америке, доказывая, с полной основательностью, как каждая следующая волна вытесняет предыдущую в средние и западные штаты; как, наконец, самая последняя волна «новой эмиграции» с пониженными требованиями переселенцев, с высылкой ими заработков на родину, застопоривает дальнейшее переселение, вызывая переход американцев сперва к ограничительным, а потом и к запретительным мерам. Русская эмиграция в Сибирь также останавливается, сталкиваясь с встречной китайской волной, с колонизацией Маньчжурии. Авторы показывают, как это встречное движение было вызвано самими же русскими, открывшими пути сообщения на север и создавшими рынок в Маньчжурии. Обе остановившиеся волны, наконец, встречаются друг с другом в Тихом океане. Последний и самый грандиозный оборот колеса замыкается, готовя старой Европе катастрофу. В мире нет больше свободного места, и «психопатическая стратегия» июльской недели 1914 г. ${ }^{20}$ является плодом превращения проблемы населения в военное движение... Война возникает в силу «слепой механической необходимости»: вследствие «искания стесненными народами свободных пространств, которых больше не существует».

При изложении в этих общих чертах, содержание последней главы несколько выигрывает сравнительно с тем, что представилось бы, если бы мы дошли в нашем изложении до последних деталей. Чтобы оставить за объяснением стихийный характер, придающий единство всей книге, авторы должны были приписать политическим деятелям

\footnotetext{
18 В оригинале: «Два могучие людские потока».

${ }^{19}$ Между двумя мировыми войнами этот термин использовался для обозначения государств, образовавшихся из западных окраин Российской империи -Эстония, Латвия, Литва, Финляндия и Польша, большая часть которой ранее также входила в состав империи.

${ }^{20}$ События, непосредственно предшествовавшие Первой мировой войне.
} 
современности сознательное и намеренное слияние со стихией. Ибо изобразить их бессознательными орудиями стихии было бы еще труднее, чем в предыдущие периоды. Прямым последствием такого сближения тенденций современной политики со всем прошлым явилось резкое осуждение этой политики. Авторы решительно высказываются против всех мер предосторожности, принимаемых современными политиками разных стран против надвигающейся катастрофы. В этих мерах они видят лишь возврат к старой традиции, стремление к «автаркии» отдельных стран, долженствующей привести к новым вооруженным столкновениям, к отягощению населения налогами, к запустению народного хозяйства, к пополнению растущих армий «излишним» населением, к уничтожению этого излишка усовершенствованными орудиями, к эпидемиям, как последствию войн, словом, ко всему, с чем мы знакомы в эпоху «абсолютизма».

Но что они могут предложить, чтобы отвести от мира угрозу всех этих грядущих ужасов? Они отвечают определенно: «разумно-организованное приспособление человечества к средствам существования». Важнейшим средством для этого приспособления является «рациональное регулирование распределения человечества на земле». Это «регулирование» авторы противополагают как прежней стихийной «интернациональной свободе передвижения и заработка», так и тем «шлагбаумам», которые разгородили современную нам Европу на непроницаемые перегородки. При таком разгораживании, неизбежно усиливается давление стран с продолжающим расти населением на страны с населением, остановившимся в росте. Надо признать вместе с авторами, что «проблема населения есть мировая проблема», и приступить, по их указанию, к созданию «международной политики населения». Без этого нельзя обеспечить всемирного мира. Но необходимыми предпосылками такой «рациональной» политики являются отказ от «суверенного права - закрывать неиспользованные для питания пространства от голодающих миллионов», отказ от «национального самоопределения, которое хотело бы сохранить навеки существующие отношения национального обладания». Наконец, эти необходимые, весьма радикальные перемены, «являющиеся теперь утопией», предполагают еще и научное знание «механических законов передвижения», которые до сих пор игнорировались, но «существование» которых (не «открытие») хотели доказать авторы разбираемой книги.

Как видим, независимо от вопроса об осуществимости предлагаемого авторами решения, нельзя не признать, что поставленный ими вопрос принадлежит к числу важнейших, связанных с разрешением настоящего кризиса (чтобы не употреблять слова «катастрофа», монополизированного известными течениями политической, - лучше сказать мировоззренческой - мысли). Если не держаться принципа «все или ничего», то можно было бы признать законность тенденций, проводимых в книге, даже и не веря в возможность их осуществления в крайней форме, какой требуют авторы. Факт международной «взаимозависимости» (interdépendance) можно считать общепризнанным в наше время. Но это признание не исключает инстинкта и политики национального самосохранения. В разумном сочетании интернационального и национального элемента и надо искать решения проблемы. Логически - это усложняет вопрос, но практически делает возможным и приближает хотя бы частичное его разрешение. Абсолютное решение «навсегда» - было бы невозможно уже и потому, что, по признанию самих авторов, 
демографический элемент проблемы - динамика населения - находится в вечном колебании. Вероятно, авторы признают и то, что демографический элемент не единственный, который необходимо принимать во внимание при периодическом пересмотре вопроса в интернациональном порядке. Напомню, что такой пересмотр уже и предусмотрен в «Пакте» Лиги Наций. Осуществление задачи, поставленной авторами, лежит, таким образом, в линии создания того международного правопорядка, начало которому положено этой первой формой международной организации. Но по степени сопротивления, которое даже эта форма все еще продолжает испытывать, можно судить о степени упорства тех «традиций и предрассудков», против которых справедливо ополчаются авторы в своей, несомненно, замечательной и ценной работе. В борьбе против этих «традиций и предрассудков» заключается и ее практическое значение.

\section{ЛИТЕРАТУРА}

Бродель Ф. (2006). Материальная цивилизация, экономика и капитализм, XV-XVIII вв. 2-е изд. Т. 1. М.: Весь Мир.

Кулишер А. (2014). Теория движения народов и гражданская война в России (перевод с французского). Предисловие и комментарии М. Тольца // Демографическое обозрение. №3: 158-173. URL: http://demreview.hse.ru/2014--3/143751896.html (дата обращения: 17.05.2015).

Кулишер М. (1887). Механические основы передвижения масс // Вестник Европы. №8: 597-635.

Милюков П. (1932). Новое объяснение хода всемирной истории // Последние новости (Париж). 1932. 6 августа. №4154: 2-3.

Милюков П.Н. (1993). Очерки по истории русской культуры. Т. 1. М.: Прогресс.

Тольц М. (2014а). Вклад семьи Кулишеров в мировую миграциологию // ДемоскопWeekly. №603-604. URL: http://demoscope.ru/weekly/2014/0603/nauka04.php (дата обращения: 17.05.2015).

Тольц М. (2014b). Забытый энциклопедист: Михаил Игнатьевич Кулишер (1847-1919) // Диаспоры. №2: 140-176.

Biraben J.-N. (2006). The History of Human Population from the First Beginnings to the Present Day // Caselli G., J. Vallin, G. J. Wunsch; [et al.]. Demography: Analysis and Synthesis. Vol. 3. Amsterdam [etc.]: Elsevier: 5-17.

Braudel F. (1960). La démographie et les dimensions des sciences de l'homme // Annales. Économies, Sociétés, Civilisations. 15(3): 493-523.

Kulischer E.M. (1948). Europe on the Move: War and Population Changes, 1917-1947. New York: Columbia University Press.

Kulischer E.M. (1954). [Рец. на] World Population and Production: Trends and Outlook. By W.S. \& E.S. Woytinsky. New York, The Twentieth Century Fund, 1953 // Political Science Quarterly. 69(2): 293-295.

Kulischer A., E. Kulischer (1932). Kriegs- und Wanderzüge. Weltgeschichte als Völkerbewegung. Berlin - Leipzig: Walter de Gruyter. 
Lorimer Fr. (1959). The Development of Demography // Ph.M. Hauser and O.D Duncan, eds. The Study of Population: An Inventory and Appraisal. Chicago, IL: University of Chicago Press: 124-179.

Miljukov P. (1933). Une nouvelle explication du cours de l'histoire universelle // Le monde slave. 10(4):127-136

Ratzel Fr. (1882-1891). Anthropogeographie. Bd. 1-2. Stuttgart: J. Engelhorn.

Ratzel Fr. (1897). Politische Geographie. München - Leipzig: R. Oldenbourg.

Timasheff N.S. (1955). Sociological Theory, Its Nature and Growth. Garden City, N.Y.: Doubleday. 


\title{
A NEW EXPLANATION OF THE COURSE OF WORLD HISTORY *
}

\section{PAVEL MILYUKOV}

\author{
Pavel Milyukov (MilJukov; 1859-1943) \\ DATE RECEIVED: MAY 2015.
}

\begin{abstract}
This publication reproduces Pavel Milyukov's detailed review of the classic book by A. Kulischer and E. Kulischer, Kriegs-und Wanderzüge. Weltgeschichte als Völkerbewegung (Berlin - Leipzig: Walter de Gruyter. 1932). Milyukov, a famous Russian historian and politician, printed this review in the Russian language emigrant newspaper "Poslednie novosti" [Latest News], which had been published by him in Paris between the two world wars and is now almost inaccessible to contemporary readers. The republication of the review is supplemented with a preface and helpful explanations. The preface provides the history of the book and notes the role of the famous Russian historian and sociologist Mikhail Kulisher [Michael Kulischer], the father of the Kulischer brothers, in the development of the original theory of mass migration movements on which the book is founded. His more than forty-year effort in collecting materials about world migration, which were utilized in the book by his sons, is also recognized.
\end{abstract}

Key words: theory of migration, wars and migrations, Alexander Kulischer [Alexandre Koulicher] (18901942), Eugene [Eugen] Kulischer (1881-1956), Mikhail Kulisher [Michael Kulischer] (1847-1919).

\footnotetext{
* Preface, Preparation of the teXt for publication and Comments by Mark Tolts.

MARK TOLTS, HEBREw UNIVERSITY OF JERUSALEM. ISRAEL. E-MAIL: mark.tolts@mail.huji.ac.il.
}

\section{REFERENCES}

Biraben J.-N. (2006). The History of Human Population from the First Beginnings to the Present Day // Caselli G., J. Vallin, G. J. Wunsch; [et al.]. Demography: Analysis and Synthesis. Vol. 3. Amsterdam [etc.]: Elsevier: 5-17.

Braudel F. (1960). La démographie et les dimensions des sciences de l'homme // Annales. Économies, Sociétés, Civilisations. 15(3): 493-523.

Braudel F. (2006). Material'naya tsivilizatsiya, ekonomika i kapitalizm, XV-XVIII vv. [Material civilization, economy and capitalism, XV-XVIII centuries]. 2-ed. Vol. 1. Moscow: Ves' Mir.

Kulischer A., E. Kulischer (1932). Kriegs- und Wanderzüge. Weltgeschichte als Völkerbewegung. Berlin - Leipzig: Walter de Gruyter.

Kulischer E.M. (1948). Europe on the Move: War and Population Changes, 1917-1947. New York: Columbia University Press.

Kulischer E.M. (1954). [Review of:] World Population and Production: Trends and Outlook. By W.S. \& E.S. Woytinsky. New York, The Twentieth Century Fund, 1953 // Political Science Quarterly. 69(2): 293-295.

Kulisher A. (2014). Teoriya dvizheniya narodov i grazhdanskaya voina v Rossii [The theory of the movement of peoples and the civil war in Russia] (Translation from French). Preface and comments by M. Tolts // Demograficheskoe obozrenie [Demographic review]. Vo1. 1. №3: 
158-173. URL: http://demreview.hse.ru/2014--3/143751896.html (date accessed: 17.05.2015).

Kulisher M.I. (1887). Mekhanicheskiye osnovy peredvizheniya mass [Mechanical foundations of the movement of the masses] // Vestnik Yevropy [Herald of Europe]. №8: 597-635.

Lorimer Fr. (1959). The Development of Demography // Ph.M. Hauser and O.D Duncan, eds. The Study of Population: An Inventory and Appraisal. Chicago, IL: University of Chicago Press: 124-179.

Miljukov P. (1933). Une nouvelle explication du cours de l'histoire universelle // Le monde slave. 10(4):127-136.

Milyukov P. (1932). Novoe obyasnenie khoda vsemirnoi istorii [A new explanation of the course of world history]// Poslednie novosti [Latest News] (Paris). 1932. 6 August. №4154: 2-3.

Milyukov P.N. (1993). Ocherki po istorii russkoi kul'tury [Outline of the history of Russian culture]. Vol. 1. Moscow: Progress.

Ratzel Fr. (1882-1891). Anthropogeographie. Bd. 1-2. Stuttgart: J. Engelhorn.

Ratzel Fr. (1897). Politische Geographie. München - Leipzig: R. Oldenbourg.

Timasheff N.S. (1955). Sociological Theory, Its Nature and Growth. Garden City, N.Y.: Doubleday.

Tolts M. (2014a). Vklad sem'i Kulisherov v mirovuyu migratsiologiyu [Kulisher family contribution to the world migration studies] // Demoscope Weekly. №603-604. URL: http://demoscope.ru/weekly/2014/0603/nauka04.php (date accessed: 17.05.2015).

Tolts M. (2014b). Zabytyi entsiklopedist: Mikhail Ignatyevich Kulisher (1847-1919) [Forgotten Polymath: Mikhail Ignatyevich Kulisher (1847-1919) // Diaspory [Diasporas]. №2: 140-176. 